\title{
Czynniki charakterystyczne dla tętniaka aorty brzusznej i jego potencjalne biomarkery
}

Factors and biomarkers characteristic for abdominal aortic aneurysm

\section{Karolina Stępień, Marta Lesiak, Aleksander L. Sieroń}

Zakład Biologii Molekularnej Katedry Biologii Molekularnej i Genetyki Wydziału Lekarskiego Śląskiego Uniwersytetu Medycznego w Katowicach

\section{STRESZCZENIE}

Tętniak aorty brzusznej (AAA) jest schorzeniem wieloczynnikowym i bezobjawowym, charakteryzującym się wysoką śmiertelnością pacjentów. Istnieje wiele indukujących go czynników, ale do tej pory nie zidentyfikowano jednego kluczowego, o podłożu molekularnym, genetycznym czy środowiskowym, który przyczynia się do powstania tętniaka. Uszkodzenie struktury macierzy zewnątrzkomórkowej, apoptoza komórek mięśni gładkich ściany naczynia i komórek śródbłonkowych poprzez czynniki degeneracyjne indukuje proces tworzenia tętniaka w ścianie naczynia. Towarzyszy temu postępujący proces zapalny. Badaniem pozwalającym na wykrycie AAA jest ultrasonografia jamy brzusznej. Nie jest to jednak rutynowe badanie przesiewowe wykonywane u wszystkich osób, dlatego do zdiagnozowania AAA dochodzi w bardzo zaawansowanym stadium choroby, co zagraża życiu pacjenta. Jedynym medycznym postępowaniem w tym przypadku pozostaje zabieg chirurgiczny, dlatego koniecznym wydaje się poznanie procesów molekularnych, biomarkerów AAA oraz genów odpowiedzialnych za mechanizm powstawania tętniaków. Umożliwiłoby to szybszą i efektywniejszą diagnostykę, a tym samym zapoczątkowałoby proces leczenia.

Choroby Serca i Naczyń 2019, 16 (4), 257-265

Adres do korespondencji:

dr n. med. Marta Lesiak

Zakład Biologii Molekularnej,

Katedra Biologii Molekularnej i Genetyki

Wydział Lekarski, Śląski Uniwersytet Medyczny w Katowicach

ul. Medyków 18, 40-752 Katowice

tel. +4832208 8385, faks +4832 2088382

e-mail: mlesiak@sum.edu.pl
Słowa kluczowe: tętniak aorty brzusznej (AAA), macierz zewnątrzkomórkowa (ECM), osteopontyna (OPN), osteoprotegryna (OPG), homocysteina (Hcy), MMP-2, MMP-9, katepsyny, geny AAA

\section{ABSTRACT}

Abdominal aortic aneurysm (AAA) is a multifactorial and asymptomatic disorder with high mortality. Numerous factors inducing AAA have been postulated, but so far no key factor with a molecular, genetic or environmental basis has been identified that would contribute to the formation of an aneurysm. Damage to the structure of the extracellular matrix, apoptosis of the vascular smooth muscle cells and endothelial cells through degenerative factors induces the process of aneurysm formation in the vessel wall. This process is accompanied by a progressive inflammatory process. The test that allows the detection of AAA is abdominal ultrasonography. However, this is not a routine screening test performed for all individuals, and therefore AAA is usually diagnosed at a very advanced stage of the disease that threatens the patient's life. The only medical procedure in AAA is surgical treatment. Therefore, it is necessary to identify molecular processes, AAA biomarkers and genes responsible for the mechanism of aneurysm formation. This would enable faster and more effective initiation of the treatment process.

Choroby Serca i Naczyń 2019, 16 (4), 257-265

Key words: abdominal aortic aneurysm (AAA), extracellular matrix (ECM), osteopontin (OPN), osteoprotegrin (OPG), homocysteine (Hcy), MMP-2, MMP-9, cathepsins, AAA genes 


\section{WPROWADZENIE}

Tętniak aorty brzusznej (AAA, abdominal aortic aneurysm) jest częstym, przebiegającym bezobjawowo schorzeniem polegającym na miejscowym poszerzeniu aorty o ponad 50\% jej prawidłowej średnicy. Postępujące poszerzanie tętnicy prowadzi do pęknięcia tętniaka, co w $85 \%$ przypadków skutkuje śmiercią pacjenta. Do tej pory nie udało się $\mathrm{w}$ pełni odpowiedzieć na pytanie, jakie czynniki leżą u podstaw powstania AAA. Dziś już niemal na pewno wiadomo, że ważną rolę odgrywają predyspozycje warunkowane genetycznie, choć nie da się również zaprzeczyć, że choroba może się rozwijać wraz ze zwyrodnieniami i osłabianiem błony znajdującej się w ścianie tętnic. W statystykach wskazuję się też na większe prawdopodobieństwo pojawienia się tętniaka u osób palących tytoń, zmagających się z nadwagą lub otyłością czy po przebytym zawale serca [1,2].

Obecnie podstawowymi metodami diagnostycznymi wykrywania AAA są badanie ultrasonograficzne (USG) i tomografia komputerowa (CT, computed tomography) jamy brzusznej. Niestety ze względu na bezobjawowy przebieg schorzenia jest ono wykrywane w bardzo zaawansowanym stadium. Rodzi to duże zagrożenie dla życia pacjenta, a jedyną metodą leczenia wciąż pozostaje zabieg chirurgiczny [1,2]. W celu polepszenia diagnostyki konieczne wydaje się więc poznanie procesów molekularnych leżących u podstaw rozwoju AAA, wykrycie jego biomarkerów oraz wskazanie genów odpowiedzialnych za mechanizm powstawania tętniaków. W niniejszej pracy podjęto próbę przedstawienia aktualnego stanu wiedzy z zakresu epidemiologii AAA, jego patogenezy i diagnostyki.

\section{EPIDEMIOLOGIA TĘTNIAKA AORTY BRZUSZNEJ}

Wykrycie AAA następuje często dopiero wtedy, gdy dochodzi do jego pęknięcia. W ostatnich latach opublikowano wiele zaleceń służących lepszemu monitorowaniu populacji zagrożonej rozwojem AAA. W szczególności dotyczą one grupy o zwiększonym ryzyku zachorowalności, jakim jest przekroczenie 50. roku życia, i głównie mężczyzn [2].

Tętniak aorty brzusznej najczęściej występuje w podnerkowym odcinku aorty. Tętnicę nazywa się tętniakową, gdy jej średnica zwiększa się o $4 \mathrm{~cm}$ lub o 50\% powyżej prawidłowego rozmiaru. Powiększona średnica aorty brzusznej wskazuje na większe prawdopodobieństwo pęknięcia tętniaka oraz wyznacza czas do podjęcia interwencji chirurgicznej [3]. Wadania populacyjne wskazują, że AAA występuje u 4-7\% mężczyzn powyżej 50. roku życia oraz u 1-2\% kobiet w wieku powyżej 55 lat [2].

\section{CZYNNIKI RYZYKA ZACHOROWANIA \\ NA TĘTNIAKA AORTY BRZUSZNEJ}

Aorta jest tętnicą typu sprężystego o trójwarstwowej budowie ściany utworzonej przez warstwy zewnętrzną, środkową i wewnętrzną. Poszczególne warstwy aorty w swej budowie zawierają charakterystyczne komórki. W warstwie zewnętrznej wyróżnia się głównie fibroblasty, które wytwarzają komponenty budowy macierzy zewnątrzkomórkowej (ECM, extracellular matrix). Komórkowymi składnikami warstwy środkowej są przede wszystkim komórki mięśni gładkich, które uczestniczą w utrzymaniu struktury naczynia poprzez kontrolę proliferacji oraz wydzielanie składników ECM, a także prawidłowego utrzymania unaczynienia i regulacji ciśnienia tętniczego. W trzeciej warstwie, wewnętrznej, występują komórki śródbłonkowe (EC, endothelial cells). Komórki te regulują odpowiedź immunologiczną oraz pełnią funkcje odżywczą i wzmacniającą naczynie. Zaburzenie struktury warstw ściany skutkuje powstaniem patologii, jaką jest AAA.

Podstawowymi czynnikami ryzyka rozwoju AAA są płeć męska, starszy wiek pacjentów, palenie tytoniu, miażdżyca, przebyta wcześniej operacja (np. amputacja) czy też czynniki genetyczne. Mimo licznych badań przesiewowych przeprowadzonych w grupach podwyższonego ryzyka zachorowania na AAA, nie jest jeszcze możliwe wykrycie tętniaków u wszystkich pacjentów. Dlatego nadal liczne są zdarzenia niespodziewane będące najczęstszą przyczyną zgonu, szczególnie wśród starszych pacjentów [3].

\section{CZYNNIKI RYZYKA POWODUJĄCE PĘKNIĘCIE TĘTNIAKA AORTY BRZUSZNEJ}

Większość AAA przebiega bez objawów klinicznych, co powoduje, że te niewykryte i nieleczone nieustannie powiększają się, aż do pęknięcia, co wiąże się z wysokim ryzykiem zgonu wynoszącym 65-90\% [4]. Poważnym czynnikiem nie tylko modulującym proces powstawania AAA, ale także wpływającym na poszerzenie oraz pęknięcie tętniaka jest palenie tytoniu. U palaczy wykryto wyższy wskaźnik rocznego przyrostu średnicy tętniaka niż u byłych palaczy i osób niepalących. Dzieje się tak, ponieważ zwiększa się stężenie proteaz, takich jak elastaza, degradującej elastynę obecną naturalnie w ścianie aorty $[4,5]$. 
Istnieją specyficzne dla płci różnice w średnicy aorty, które warunkują proces pęknięcia tętniaka. Choć AAA występuje głównie u mężczyzn, to pęknięcia małych tętniaków zdarzają się 3 razy częściej u kobiet. Istotny jest fakt, że średnica tętniaka, który może pęknąć, jest niższa u kobiet niż u mężczyzn i wynosi odpowiednio 5 i $6 \mathrm{~cm}$. Ponadto w przypadku tętniaków mierzących 5-6 cm ryzyko pęknięcia jest aż 4 razy wyższe u kobiet. Jest to spowodowane faktem, że u kobiet średnica zdrowej aorty jest mniejsza niż u mężczyzn $[3,4]$.

Średnica oraz kształt tętniaka są najważniejszymi czynnikami prowadzącym do jego wzrostu i pęknięcia. Wyniki przeprowadzonych badań wskazują, że wśród mężczyzn z AAA o średnicy $3 \mathrm{~cm}$ roczny przyrost tętniaka wynosił 1,28 mm. Natomiast gdy średnica AAA wynosiła $5 \mathrm{~cm}$, to roczny przyrost tętniaka wynosił już 3,61 mm. Z tych pomiarów wynika, że każde zwiększenie średnicy AAA o 0,5 mm prowadzi do zwiększenia wskaźnika rocznego przyrostu tętniaka o 0,59 mm [4, 5]. Kształt tętniaka wpływa również na wyższe ryzyko jego pęknięcia i wynaczynienia krwi. Średnica tętniaka oraz jego asymetria są bowiem istotnym wyznacznikiem naprężeń mechanicznych w ścianie aorty. W małych tętniakach, czyli takich, których średnica jest mniejsza bądź równa $5 \mathrm{~cm}$, maksymalne naprężenie występuje na tylnej ścianie aorty. Natomiast w dużych tętniakach maksymalne naprężenie występuje na przedniej ścianie aorty. Podsumowując, maksymalne ciśnienie wpływające na tętniak wzrasta w sposób nielinearny wraz ze wzrostem średnicy lub asymetrii $[4,5]$.

\section{PATOGENEZA TEৃTNIAKA AORTY BRZUSZNEJ}

Patogeneza AAA jest złożonym procesem patofizjologicznym, w którym jest zaangażowanych zarówno kilka procesów biologicznych, jak i czynników ryzyka. Cechy charakterystyczne AAA to występujący proces zapalny w ścianie tętnicy, apoptoza komórek mięśni gładkich naczynia, degradacja ECM oraz niewątpliwie stres oksydacyjny i nadmierna aktywność szlaków proteolitycznych [2-5].

Powiększające się tętniaki mogą pęknąć, co wiąże się z wysokim ryzykiem śmierci pacjentów. Prawdopodobnie dzieję się tak w wyniku utraty włókien elastyny i miejscowego osłabienie kolagenu oraz mięśni gładkich. Stwierdza się, że w AAA występuje do 90\% mniej włókien elastyny niż w prawidłowej tętnicy. Osłabienie warstw tętnicy współgra ze zgrubieniem warstw aorty oraz ze zwłóknieniem włóknistym. Ilość śródściennego kolagenu w AAA nie różni się znacząco od jego ilości w zdrowej tęt- nicy, mogą natomiast występować różnice w jego organizacji w fibrylach i przez to jakości tych fibryli decydującej o właściwościach mechanicznych tkanki [5].

\section{DEGRADACJA MACIERZY ZEWNĄTRZKOMÓKOWEJ}

Macierz zewnątrzkomórkowa wypełnia przestrzeń między tkankami i narządami. Jej głównymi składnikami są glikoproteiny, proteoglikany, kolagen oraz elastyna [6].

Aorta brzuszna, ze względu na pełnioną funkcję, jest narażona na działanie czynników mechanicznych o dużej sile, takich jak ciśnienie tętnicze. Dzięki dobrze zorganizowanej strukturze architektonicznej jest ona w stanie prawidłowo przenosić obciążenia mechaniczne spowodowane tętniczym przepływem krwi [7]. Głównymi ilościowo składnikami budulcowymi aorty, która jest tętnicą typu sprężystego, są kolagen i elastyna. Białka te warunkują jej właściwości mechaniczne [8].

Rozciągliwość elastyny sprawia, że jej włókna mogą dwukrotnie zwiększyć swoją długość, a następnie wrócić do pierwotnej długości, co zapewnia sprężystość aorty [7]. Dzięki temu naczynie może stawiać opór mechanicznemu obciążeniu towarzyszącemu ciśnieniu tętniczemu. Elastyna jest syntetyzowana wyłącznie w okresie rozwoju człowieka w komórkach mięśni gładkich aorty. Włókna elastyny układają się okrężnie, tworząc faliste blaszkowate warstwy. Takie ułożenie zapewnia tętnicy wyjątkową elastyczność. Ilość blaszek jest zmienna w danym odcinku naczynia. Najwięcej jest ich w łuku aorty i okolicach serca, a ich liczba maleje im bliżej tętnic biodrowych. Elastyczność tętnicy zależy od ilości blaszek w danym odcinku, zatem ich utrata sprzyja powstawaniu tętniaka. Okres półtrwania elastyny wynosi około 70 lat, co sprawia, że u osób w podeszłym wieku częściej pojawiają się tętniaki $[7,8]$. Proces starzenia się oraz nadciśnienie tętnicze przyczyniają się do degradacji i fragmentacji elastyny, co szczególnie sprzyja rozwojowi tętniaka $[1,7,8]$.

Kolagen jest białkiem o budowie potrójnej helisy stabilizowanej wiązaniami poprzecznymi, co sprawia, że włókna kolagenowe cechują się ogromną wytrzymałością mechaniczną i nie są podatne na rozciąganie. Kolagen, w przeciwieństwie do elastyny, jest o 20 razy mniej rozciągliwy. Zbyt mocne rozciągnięcie kolagenu powoduje nieodwracalne zmiany strukturalne oraz utratę wytrzymałości [7,8]. Zaburzenie metabolizmu kolagenu wpływa na układ włókien elastyny, co w konsekwencji osłabia ścianę tętnicy. Wskutek tego zwiększa się zawartość prekursorowych form kolagenu I i III, a fibrynogeneza włókien kolagenowych jest zaburzona. Poznanie przyczyny 
zaburzenia metabolizmu kolagenu w tkance jest utrudnione, gdyż jego ilość zależy od natężenia jego syntezy i degradacji w wyniku oddziaływania wielu czynników. Włókna elastyny i kolagenu wzajemnie się uzupełniają, tworząc sieć zabezpieczającą naczynie. Jakiekolwiek zaburzenie struktury tych białek skutkuje więc powstaniem, rozwojem, a w końcu pęknięciem tętniaka [8].

Macierz zewnątrzkomórkowa jest istotnym składnikiem budulcowym poszczególnych warstw ściany aorty. Nieprawidłowa przebudowa ściany naczynia wraz z niefizjologicznymi siłami mechanicznymi wywieranymi przez ciśnienie tętnicze wpływa niekorzystnie na ekspansję ściany naczynia oraz prowadzi do powstania AAA i ostatecznie jego pęknięcia. Zwiększone mechaniczne naprężenie oraz obciążenie ścian naczynia indukuje nieprawidłową przebudowę ECM w ścianie tętnicy, co również przyczynia się do powstania AAA [9].

Główną rolę w degradacji i przebudowie ECM odgrywają metaloproteinazy macierzy zewnątrzkomórkowej (MMP, matrix metalloproteinases). Enzymy te w warunkach fizjologicznych odpowiadają za przebudowę tkanek w rozwijającym się zarodku, gojenie ran, migrację komórek, różnicowanie tkanek oraz tworzenie naczyń krwionośnych (angiogenezę) i przebudowę tkanek $[6,10]$. Głównym źródłem MMP są komórki mięśni gładkich naczyń, śródbłonka, fibroblasty i komórki mięśniowe serca, a w miejscach objętych procesem zapalnym również makrofagi $[10,11]$. Wspólne cechy MMP to degradacja i przebudowa macierzy, która umożliwia poruszanie się komórek, zarówno w prawidłowych procesach fizjologicznych, jaki w stanach zapalnych [6,10,11]. Nadmierna aktywność MMP prowadzi do utraty składników ściany naczynia, głównie elastyny i kolagenu. Wszelkie nieprawidłowe zmiany w strukturze macierzy prowadzą do zachwiania równowagi i aktywności szlaków sygnałowych. Prowadzi to do powstania zwłóknień oraz śmierci komórek. Za równowagę macierzy odpowiada korelacja między MMP i ich inhibitorami tkankowymi (TIMP, tissue inhibitors of metalloproteinases) [11]. Są one naturalnymi, tkankowo specyficznymi, endogennymi inhibitorami MMP i występują w większości tkanek, w przestrzeniach międzykomórkowych, osoczu krwi i innych płynach ustrojowych [12-14].

Wyróżnia się cztery rodzaje TIMP oznaczone kolejnymi liczbami 1, 2, 3 i 4 [15]. Inhibitory te wiążą się z komórkami poprzez białka powierzchniowe. Inhibitory tkankowe metaloproteinaz są zdolne do hamowania aktywności proteolitycznej wszystkich poznanych MMP.
Jednak skuteczność tego hamowania różni sięzależnie od rodzaju TIMP [13]. Inhibitory tkankowe metaloproteinaz wiążą się z MMP za pomocą wiązania kowalencyjnego, a mechanizm hamowania polega na uniemożliwieniu dostępu substratu do miejsca katalitycznego [15]. Równowaga między MMP a aktywnością TIMP może wpływać na prawidłowe procesy oraz na procesy związane z przebudową tkanek, angiogenezą, a także tworzeniem guzów [12]. Aktywność TIMP poprzez hamowanie MMP decyduje o równowadze między syntezą i proteolityczną degradacją składników ECM. Zmiana prawidłowego funkcjonowania MMP prowadzi do zwiększonej proteolizy ECM, a zmiana prawidłowego funkcjonowania TIMP prowadzi do ochrony oraz zmniejszenia proteolizy ECM. Interakcja kompleksów MMP/TIMP nie dotyczy tylko rozkładu ECM; jest to złożony proces z udziałem białek biologicznie czynnych, w tym cytokin, hemokin oraz innych białek powierzchniowych komórki. Regulacja biologicznie czynnych białek z udziałem kompleksów MMP/TIMP pośrednio wpływa na przebudowę macierzy $[12,13]$. Rola TIMP w regulacji przebudowy ECM zależy od specyficznej metaloproteinazy hamowanej przez swoisty TIMP w tkance. Duża część rodziny TIMP bierze udział w zmniejszaniu degradacji ECM przez różnorodne MMP [13].

\section{PROCES ZAPALNY PRZEBIEGAJĄCY W ŚCIANIE TĘTNIAKA AORTY BRZUSZNEJ}

Powszechnie wiadomo, że w każdym tętniaku zachodzi postępujący proces zapalny, co potwierdza występowanie w nim takich komórek, jak makrofagi, limfocyty, komórki dendrytyczne oraz plazmatyczne. W AAA stan zapalny towarzyszy tętniakowi od momentu jego powstania i utrzymuje się przez cały czas [16, 17]. Ważną rolę w procesie tworzenia AAA odgrywają cytokiny. W odpowiedzi immunologicznej pojawia się czynnik martwicy nowotworów alfa (TNF $\alpha$, tumor necrosis factor alpha). Wzrost stężenia TNF $\alpha$ następuje zarówno w osoczu pacjentów z AAA, jak i w tkankach występujących u nich tętniaków $[16,17]$.

\section{DIAGNOZA TĘTNIAKA AORTY BRZUSZNEJ}

W wielu przypadkach AAA jest schorzeniem bezobjawowym, co znacznie utrudnia jego wykrycie. Podstawowa metoda pozwalająca wykryć AAA to badanie ultrasonograficzne (USG) jamy brzusznej. Obecnie nie ma jeszcze środka farmakologicznego, za pomocą którego można wyleczyć pacjenta z tętniaka bez konieczności 
przeprowadzenia operacji. Zabieg operacyjny wiąże się z wysokim ryzykiem i przyczynia się do wysokiej umieralności wśród pacjentów. Dlatego istotnym elementem, który pozwoli szybko zdiagnozować oraz leczyć AAA, może być poznanie molekularnych procesów zachodzących w tętniaku oraz wskazanie biomarkerów AAA.

Do najbardziej znanych biomarkerów przyczyniających się do powstania AAA należą: homocysteina (Hcy, homocysteine), osteopontyna (OPN, osteoprotegrin), osteoprotegeryna (OPG, osteopontin), katepsyny, MMP-2 oraz -9, interleukina 2, 6 i 10 oraz białko C-reaktywne (CRP, C-reactive protein) i mikroRNA miR29c-3p.

\section{ROLA HOMOCYSTEINY W PROCESIE TWORZENIA TĘTNIAKA AORTY BRZUSZNEJ}

Homocysteina jest aminokwasem o właściwościach antyheparynowych, który nie występuje w strukturze łańcuchów polipeptydowych. W badaniach wykazano, że bierze ona udział w patogenezie AAA, dlatego monitorowanie stężenia Hcy w osoczu krwi pacjenta służy do oceny zagrożeń powiązanych z powstawaniem i wzrostem AAA. Ponadto Hcy uznano za niezależny czynnik ryzyka chorób układu sercowo-naczyniowego i naczyniowo-mózgowych, ponieważ jej obniżone stężenie powiązano z niskim ryzykiem wystąpienia tych chorób [18]. Homocysteinę uważa się również za czynnik ryzyka choroby miażdżycowej, która znacząco wpływa na proces tworzenia AAA. Ponadto Hcy stymuluje proces elastolizy w naczyniach tętniczych poprzez aktywację elastyny i MMP [18-21].

Tętniak aorty brzusznej jest chorobą wieloczynnikową i wieloetapową, a mechanizmy zachodzące podczas tworzenia AAA są ze sobą bardzo mocno powiązane. Homocysteina wpływa na każdy z nich. Z badań wynika, że działanie Hcy zachodzi prawdopodobnie na wielu poziomach, na przykład proteolitycznym, trombogennym czy też na aterogennym [19]. Homocysteina wykazuje właściwości cytotoksyczne, które zaburzają funkcjonowanie śódbłonka naczyniowego. Utrzymujące się przez długi czas wysokie stężenie Hcy może prowadzić do jego uszkodzenia. Komórki śródbłonka przestają produkować tlenek azotu (NO, nitric oxide), który ma właściwości wazokonstrakcycje, obkurczające naczynia krwionośne. Co więcej, dysfunkcja w produkcji NO prowadzi również do wzmożonej aktywności procesu zapalnego i proliferacji komórek mięśni gładkich [20,21]. Oprócz dysfunkcji mięśni gładkich na przebudowę ECM wpływa niekorzystnie wzmożone wydzielanie MMP. Jak już wcześniej wspomniano, w two- rzeniu AAA ogromną rolę odgrywa proces zapalny. Homocysteina pobudza wydzielanie chemokin i cytokin przez monocyty, co osłabia działanie limfocytów T [19].

\section{ROLA OSTEOPONTYNY I OSTEOPROTEGRYNY W PROCESIE TWORZENIA TĘTNIAKA AORTY BRZUSZNEJ}

Osteopontyna i osteoprotegeryna są białkami o szerokim spektrum działania. W badaniach wykazano, że oba te białka biorą czynny udział w aktywacji komórek układu immunologicznego oraz zaostrzają zmiany miażdżycowe wynikające ze zwapnienia ścian naczyń krwionośnych i proteolizy białek ECM. Przyczyniają się one do powstawania chorób układu sercowo-naczyniowego [22].

Osteopontyna jest białkiem prozapalnym ECM. Udowodniono jej rolę w powstawaniu zaburzeń funkcji serca po urazie niedokrwiennym, a także patologicznym rekrutowaniu neutrofilów, apoptozie i amplifikacji stanu zapalnego przez degranulację komórek tucznych i produkcję immunoglobulin. Ponadto OPN, podobnie jak Hcy, jest zaangażowana w rozwój choroby miażdżycowej i proteolizę. Nasila więc degenerację w ścianie aorty [23]. Osteopontyna jest wydzielana w odpowiedzi na stres przez osteoblasty, makrofagi, a w ścianie naczyń krwionośnych przez komórki mięśni gładkich oraz śródbłonka. Regulacja jej ekspresji odgrywa kluczową rolę w migracji makrofagów i komórek mięśni gładkich, co jest ściśle powiązane z przebudową naczyń oraz rozwojem choroby miażdżycowej. Stężenie OPN w osoczu wiąże się ściśle z rozwojem chorób układu sercowo-naczyniowego, w tym AAA $[23,24]$.

Wyniki wcześniejszych badań ujawniły, że u pacjentów z AAA występują podwyższone stężenia OPNi OPG we krwi, co również odnosi się do zmiany średnicy AAA $[22,24,25]$. Powiązano również CRP z obecnością OPN. Obecność CRP świadczy o prozapalnych właściwościach OPN. Stwierdzono, że OPN ma nie tylko charakter chemotaktyczny ale również ma zdolność aktywacji komórek układu immunologicznego, takich jak: makrofagi, limfocyty T, przez co potęguje komórkową odpowiedź immunologiczną. W ten sposób powiązano podwyższone stężenie OPN z rozwojem tętniaka. Natomiast nie wykazano związku tego rozwoju z CRP [22, 27].

Osteoprotegryna jest cytokiną zaliczaną do nadrodziny receptora czynnika martwicy nowotworu (TNFR, tumor necrosis factor receptor). W układzie tętniczym OPG jest produkowana przez komórki mięśni gładkich oraz komórki śródbłonkowe. Osteoprotegeryna jest zaangażowana w układ OPG/RANKL/RANK. Funkcją OPG 
jest hamowanie połączenia ligandu osteoprotegryny RANKL z receptorem komórkowym RANK. Osteoprotegrynę wiąże się także $\mathrm{z}$ występowaniem i nasilaniem choroby wieńcowej oraz z podwyższonym populacyjnym ryzykiem wystąpienia chorób układu sercowo-naczyniowego.

\section{ROLA METALOPROTEINAZ (MMP-2, -9) W PROCESIE TWORZENIA TĘTNIAKA AORTY BRZUSZNEJ}

Metaloproteinazy macierzy pozakomórkowej stanowią rodzinę edopeptydaz pełniących dominującą rolę w homeostazie ECM. Spośród 28 zidentyfikowanych metaloproteinaz, $22 \mathrm{z}$ nich występują $\mathrm{w}$ organizmie człowieka. Należą one do różnych rodzin, w zależności od specyficznego substratu będącego składnikiem ECM $[6,10,11]$. Do najważniejszych metaloproteinaz, które współdziałają w utrzymaniu homeostazy w organizmie oraz rozwoju i przebiegu reakcji zapalnych [6] zalicza się MMP-2 oraz MMP-9 (odpowiednio żelatynaza A i B). Odgrywają one rolę $w$ patogenezie tętniaka aorty oraz innych zaburzeniach układu sercowo-naczyniowego $[10,15]$.

Metaloproteinaza 2 jest syntetyzowana przez komórki mięśni gładkich, makrofagi oraz fibroblasty, a jej substratami są liczne białka ECM, w tym elastyny. Zmiany w strukturze MMP-2 prowadzą do zmian patologicznych naczyń oraz tworzenia się małych tętniaków. Dlatego uważa się ją za główną metaloproteinazę występującą w małych AAA [27]. Zaobserwowano, że w procesach patologicznych aktywność MMP-2 pojawia się nie tylko $\mathrm{w}$ miejscach chorobowych, ale także $\mathrm{w}$ tych nieobjętych zmianami patologicznymi [27].

W organizmie ludzkim MMP-9 pełni wiele funkcji, między innymi odpowiada za degradację macierzy oraz błon podstawnych. Ta aktywność umożliwia migrację leukocytów do miejsca objętego stanem zapalnym. Ponadto MMP-9 odpowiada za degradację oraz rozkład chemokin i utrzymanie homeostazy w wielu układach organizmu [6].

Jak już wcześniej wspomniano, MMP-9, podobnie jak MMP-2, należy do rodziny żelatynaz i cechuje ją aktywność proteolityczna prowadząca do degradacji ECM, która jest powodem niekorzystnych zmian w ścianie aorty i jej rozwarstwienia. Nadaktywność aortalnych komórek śródbłonkowych, komórek mięśni gładkich i naciekających komórek zapalnych jest powodem nadprodukcji znacznej ilości MMP-9 uwalnianej do krwi. To sprawia, że MMP-9 odgrywa ważną rolę w tworzeniu AAA, co potwierdzono w badaniach, w których wykazano, że podwyższone stężenie MMP-9 występowało u pacjentów z AAA [28].

Mechanizmowi tworzenia AAA towarzyszy proces zapalny, podczas którego komórki układu odpornościowego produkują między innymi MMP-9. Początkowo uważano, że wydzielają ja tylko neutrofile. Obecnie wiadomo, że MMP-9 jest produkowana nie tylko przez jeden typ komórek, lecz przez takie komórki, jak monocyty, makrofagi, limfocyty i mastocyty. W pierwszych etapach stanu zapalnego MMP-9 produkowana jest przez makrofagi i mastocyty, natomiast $\mathrm{w}$ późniejszych stadiach przez neutrofile i makrofagi zapalne. $Z$ czasem neutrofile stają się głównym miejscem syntezy żelatynazy B. Warto dodać, że MMP-9 jest syntetyzowana i magazynowana w II- i III-rzędowych ziarnistościach na etapie dojrzewania tych komórek. Cytokiny mają zdolność do aktywacji neutrofili, przez co wcześniej zsyntezowana żelatynaza B jest wydzielana bez wznowienia jej syntezy. Proces ten jest bardzo gwałtowny i trwa zaledwie kilkanaście minut [6].

Zbyt wysoka aktywność MMP-9 i wzmożona degradacja macierzy przyczyniają się do patogenezy chorób układu krwionośnego, między innymi tętniaków aorty. Zaobserwowano zwiększoną aktywność MMP-9 w ścianie pękniętych tętniaków, ale nie na etapie powstawania tej zmiany chorobowej, czyli przeciwnie niż w przypadku MMP-2 [6, 10, 11, 15, 27].

Korelację stężenia MMP-9 z maksymalną średnicą aorty uznano za kliniczny marker wzrostu AAA. Aktywność MMP-9 zmienia się w zależności od średnicy aorty. Jej ekspresja jest podwyższona w tętniakach o średnicy od 5 do 6-9 cm. Stwierdzono również powiązanie MMP-9 z CRP oraz z Hcy, co świadczy o tym, że MMP-9 może być istotnym biomarkerem diagnostycznym u pacjentów z AAA $[10,11,18]$.

\section{ROLA KATEPSYN W TWORZENIU TĘTNIAKA AORTY BRZUSZNEJ}

Za najważniejszą funkcję katepsyn uważa się udział w procesach układu immunologicznego. Katepsyny zalicza się do białek lizosomalnych, które są aktywowane w środowisku kwaśnym. $W$ tej grupie u człowieka zidentyfikowano katepsyny: B, C, D, F, G, H, K, L O, S, V, $W$ i podtyp $X$. Białka te mogą być aktywowane poprzez hydrolizę ich nieaktywnych prekursorów, czyli zymogenów, w środowisku kwaśnym, takim jakie na przykład występuje w lizosomach. Czynniki ryzyka, AAA takie jak palenie tytoniu czy też miażdżyca naczyń, powodują zniszczenie komórek śródbłonka, prowadząc do zwięk- 
szenia przepuszczalności błony lizosomalnej, co indukuje wydzielanie katepsyn. Ich wydzielanie może być więc regulowane przez zmianę $\mathrm{pH}$, a także przez endogenny inhibitor katepsyny, jakim jest cystatyna C. Za wydzielanie katepsyn są także odpowiedzialne TNF $\alpha$ i interferon $\gamma$, które mogą aktywować to wydzielanie w komórkach śródbłonkowych naczyń (VEC, vascular endothelia cells), makrofagach oraz komórkach mięśni gładkich naczyń (VSMC, vascular smooth muscle cells) [29, 30].

Aktywność katepsyn wykryto u osób z chorobami układu sercowo-naczyniowego. Natomiast w AAA ujawniono ich działanie podczas tworzenia się tętniaka. Badania immunohistochemiczne oraz wyniki analizy metodą Western blot wykazały brak katepsyny $\mathrm{L}$ w prawidłowych naczyniach. Zaobserwowano je jednak w tkankach AAA. Różnice te były widoczne również w ekspresji podtypów katepsyn w niezmienionych patologicznie naczyniach w porównaniu z tkankami AAA. W AAA komórki śródbłonkowe wydzielały katepsyny D, B, Koraz S, natomiast komórki mięśni gładkich produkowały wszystkie typy katepsyn. Postawiono tezę, że stężenie katepsyny $S$ jest powiązane $\mathrm{z}$ wielkością tętniaka, a stężenie katepsyny $\mathrm{D}$ jest znacznie bardziej podwyższone u pacjentów z AAA niż u osób zdrowych [29].

Z raportów badań wynika, że katepsyny wpływają na strukturę ECM poprzez degradację fibryli kolagenowych. Poziom syntezy kolagenu istotnie wpływa na utrzymanie struktury ECM, a zaburzenie tej struktury prowadzi do uszkodzenia ścian naczynia. Badania katepsyny S ujawniły jej ścisły związek z degradacją kolagenu typu III [31]. Można więc wnioskować, że katepsyny mają bezpośredni wpływ na patogenezę AAA. Stosunki między AAA i różnymi podtypami katepsyn, a także interakcje katepsyn z innymi czynnikami ryzyka AAA oraz sposób działania katepsyn w różnych stadiach rozwojowych AAA są niezmiernie ważne. Jednak uznanie ich dobre biomarkery diagnostyczne AAA wymaga dalszych badań [29-31].

\section{UWARUNKOWANIA GENETYCZNE POWSTAWANIA TĘTNIAKA AORTY BRZUSZNEJ}

Pierwsze badania, w których sugerowano podłoże genetyczne AAA, pojawiły się już w 1977 roku — opublikowano wtedy opis przypadku trzech braci zoperowanych z powodu pękniętych tętniaków. To rodzinne występowanie AAA dało podstawę do podejrzewania istnienia rodzinnych predyspozycji do tej choroby. Dziś nie ma wątpliwości, że AAA jest chorobą, w której rozwoju duże znaczenie mają geny. Jak już wcześniej wspomniano, za ważne dla rozwoju AAA uważa się wiele czynników środowiskowych, a ostatnio również czynniki genetyczne. W celu zidentyfikowania genów biorących udział w tworzeniu tętniaka przeprowadza się badania asocjacyjne genów kandydackich. Wybór konkretnych genów odbywa się na podstawie analizy funkcji biologicznej, jaką pełnią, oraz analizy ich potencjalnej roli w patogenezie badanej choroby. Za najważniejsze dla AAA uważa się między innymi nieprawidłową strukturę włókien sprężystych, zarówno kolagenowych, jaki elastyny, czy też udział enzymów uczestniczących w degradacji ECM.

Do określenia podłoża genetycznego AAA wykorzystuje się między innymi badania asocjacyjne całego genomu (GWAS, genome-wide association study). Polegają one na porównaniu sekwencji całych genomów osób w grupach badanej i kontrolnej, a następnie narzędziami bioinformatycznymi analizuje się znaczenie wykrytych polimorfizmów genów.

W kilku przeprowadzonych badaniach szukano związku specyficznych genetycznych markerów AAA, uwzględniając przypuszczalne geny związane z AAA. Udało się wykryć tylko kilka takich genów. Metaanaliza genów lub przypuszczalnych genów powiązanych z AAA wykazała ich dodatnią korelację z wykrytymi następującymi polimorfizmami: MMP-3 rs3025058 [33], SRT1 rs599839 [34], TGFBR rs764522 i rs1036095 [35].

Z kolei badania polimorfizmów genomowych ujawniły powiązania AAA z polimorfizmami pojedynczych nukleotydów (SNP, single-nucleotide polymorphisms), takimi jak DAB2IP rs7025486 [36], chromosom 3p12.3 rs763518 [37] i LRP1 rs1466535 [38]. Natomiast większość wykrytych polimorfizmów nie wykazywała prostej zależności $\mathrm{z}$ mechanizmem tworzenia AAA. Dlatego w opisie ewentualnego uwarunkowania genetycznego musi zostać określone, czy występowanie SNP nie jest losowe. Wyniki ostatnio opublikowanych badań wskazują, że modyfikacja epigenetyczna i metylacja DNA również mogą mieć genetyczny wpływ na powstawanie AAA [39].

Wskazanie grupy genów przyczyniających się do powstania AAA znacznie poprawiłoby diagnostykę i polepszyło terapię medyczną służącą stabilizacji rozwijających się tętniaków. Badaczom udało się zidentyfikować geny, których ekspresja jest podwyższona u pacjentów z zaawansowanym AAA i u których doszło do jego pęknięcia. Do tej grupy genów zalicza się między innymi: HILPDA, ANGPTL4, LOX, SRPX2, FCGBP. Druga grupa genów o podwyższonej ekspresji wykrytej u pacjentów z pękniętym AAA to: ADAMTS9, STC1, GFPT2, GAL3ST4, 
CCL4L1. Geny z obu grup są biologicznie związane z procesami angiogenezy i adipogenezy. Dodatkowo w odniesieniu do genów wymienionych $\mathrm{w}$ grupie pierwszej wykazano korelację między natężeniem ich ekspresji a średnicą tętniaka [40].

Białko angiopoetynopodobne 4 (ANGPTL4, angiopoietin-like 4) jest białkiem macierzy, które poprzez wiązanie integryny i sygnalizację z udziałem przekaźnika sygnału i aktywatora transkrypcji 3 (STAT3, signal transducer and activator of transcription 3) sprzyja rozwojowi angiogenezy. Z kolei SRPX2, czyli proteoglikan siarczanu chondroityny, bierze udział w proces angiogenezy, ponieważ uczestniczy we wczesnej fazie przebudowy śródbłonka oraz reguluje migrację jego komórek. Ponadto oksydaza monoaminowa (MAO, monoamine oxidase) bierze czynny udział w procesie angiogenezy guza poprzez inicjację migracji komórek, a ADAMTS9 (ADAM metallopeptidase with thrombospondin type 1 motif, 9) działa jako antyangiogenna metaloproteinaza i ulega ekspresji w komórkach śródbłonka mikronaczyń. Zwiększona neowaskularyzacja, czyli tworzenie się nowych naczyń obserwowane w warstwie środkowej dużych i pękniętych tętniaków, sugeruje, że objawy proangiogenne mają znaczenie w tworzeniu AAA. Nie jest jasne, czy pęknięcie tętniaka jest spowodowane nasileniem angiogenezy, beztlenowymi warunkami, w jakich rozwija się tętniak, czy też molekularnymi procesami zachodzącymi w AAA [40].

Warunki beztlenowe towarzyszą procesowi powstawania AAA. Czynnik indukowany hipoksją $1 \alpha$ (HIF- $1 \alpha$, hypoxia-inducible factor 1-alpha) jest wysoce powiązany z ekspresją genów w pękniętych tętniakach. Angiogeneza indukowana przez niskie ciśnienie parcjalne tlenu oraz wszystkie geny kandydujące do roli $\mathrm{w}$ tych procesach zbiegają się w głównym regulatorze HIF-1 $\alpha$, który może napędzać molekularne procesy osłabiające ścianę tętniaka; HIF-1 $\alpha$ jest zaangażowany w odpowiedź komórkową na ciśnienie parcjalne tlenu. W normalnych warunkach tlenowych ekspresja genu HIF-1 $\alpha$ jest niska, a okres półtrwania białka krótki. Hipoksja stabilizuje HIF-1 $\alpha$, hamując w ten sposób degradację białeki powodującjego akumulację [40].

\section{PODSUMOWANIE}

Tętniak aorty brzusznej jest wieloczynnikową, bezobjawową i potencjalnie śmiertelną chorobą. Na rozwój tego schorzenia wpływają czynniki genetyczne, środowiskowe oraz molekularne. Przyczyniają się one znacząco do inicjacji patologicznych procesów, które degradują prawidłową strukturę tętnicy $[3,12,16]$. Schorzenie to jest bardzo trudne do zdiagnozowania ze względu na brak występowania objawów przez długi okres jego rozwoju. Podstawowym badaniem pozwalającym wykryć AAA pozostaje USG jamy brzusznej lub CT. Z powyższych powodów do diagnozy AAA dochodzi niestety w bardzo zaawansowanym stadium choroby, co tłumaczy wysoką umieralność pacjentów. Obecnie jedyną metodą leczenia AAA jest zabieg chirurgiczny, który jednak wiąże się ze znacznym narażeniem życia pacjentów [3].

Ze względu na wieloczynnikowość AAA ważne jest określenie prawdopodobieństwa wystąpienia choroby na podstawie biomarkerów. Do wskazania biomarkerów AAA niezbędne jest poznanie procesów molekularnych, jakie zachodzą w ścianie aorty, inicjujących proces chorobotwórczy. Wykrycie takich biomarkerów ułatwi diagnostykę pacjentów już we wczesnych etapach tej choroby, co z kolei przyczyni się do zmniejszenia śmiertelności.

\section{KONFLIKT INTERESÓW}

Autorzy deklarują brak konfliktu interesów.

\section{PIŚMIENNICTWO}

1. Humphrey JD, Holzapfel GA. Mechanics, mechanobiology, and modeling of human abdominal aorta and aneurysms. J Biomech. 2012; 45(5): 805-814, doi: 10.1016/j.jbiomech.2011.11.021, indexed in Pubmed: 22189249

2. Davis FM, Rateri DL, Daugherty A. Abdominal aortic aneurysm: novel mechanisms and therapies. Curr Opin Cardiol. 2015; 30(6): 566-573, doi: 10.1097/HCO.0000000000000216, indexed in Pubmed: 26352243.

3. Kuivaniemi H, Ryer EJ, Elmore JR, et al. Understanding the pathogenesis of abdominal aortic aneurysms. Expert Rev Cardiovasc Ther. 2015; 13(9): 975-987, doi: 10.1586/14779072.2015.1074861, indexed in Pubmed: 26308600.

4. Khan S, Verma V, Verma S, et al. Assessing the potential risk of rupture of abdominal aortic aneurysms. Clin Radiol. 2015; 70(1): 11-20, doi: 10.1016/j.crad.2014.09.016, indexed in Pubmed: 25544065.

5. Schmitz-Rixen T, Keese M, Hakimi M, et al. Ruptured abdominal aortic aneurysm- epidemiology, predisponding factoram and biology. Langenbecks Arch Surg. 2016; 401(3): 275-288, doi: 10.1007/s00423016-1401-8, indexed in Pubmed: 27001684

6. Kołaczkowska E. Metaloproteinaza 9 jako szczególny przedstawiciel metaloproteinaz macierzy zewnątrzkomórkowej: rola w napływie i apoptozie neutrofili w trakcie reakcji zapalnej. Post BiolKomórki. 2010; 37: 471-499.

7. Witkiewicz W, Gnus J, Hauzer W, et al. Charakterystyka właściwości biomechanicznych ścian aorty brzusznej. Acta Angiol. 2007; 13: 122-129

8. Kowalewski R, Panek B, Pałka J, et al. Ocena wybranych czynników wpływających na metabolizm kolagenu w ścianie tętniaka aorty brzusznej. Acta Angiol. 2007; 13: 56-64

9. Triggle CR, Samuel SM, Ravishankar S, et al. The endothelium: influencing vascular smooth muscle in many ways. Can J Physiol Pharmacol. 2012; 90(6): 713-738, doi: 10.1139/y2012-073, indexed in Pubmed: 22625870 
10. Fic P, Zakrocka I, Kurzepa J, et al. Matrix metalloproteinases and atherosclerosis. Postepy Hig Med Dosw. 2011; 65: 16-27, doi: 10.5604/17322693.931536.

11. Trojanek BJ. Rola metaloproteinaz macierzy zewnątrzkomórkowej i tkankowych inhibitorów metaloproteinaz w nadciśnieniu tętniczym. Patogeneza nadciśnienia a problem otyłości. Post Bioch. 2015; 61: 356-358.

12. Qin $Y, C a o X u$, Yang $Y$, et al. Cysteine protease cathepsins and matrix metalloproteinases in the development of abdominal aortic aneurysms. Future Cardiol. 2013; 9(1): 89-103, doi: 10.2217/fca.12.71, indexed in Pubmed: 23259477.

13. Arpino V, Brock M, Gill SE. The role of TIMPs in regulation of extracellular matrix proteolysis. Matrix Biol. 2015; 44-46: 247-254, doi: 10.1016/j.matbio.2015.03.005, indexed in Pubmed: 25805621.

14. Dziankowska- Ba, Waszczykowska E, Żebrowska A. Udział metaloproteinaz i ich inchibitorów w patomechanizmie wybranych chorób skóry. Alergia Astma Immunologia. 2004; 9: 71-79.

15. Kuna J, Kuna A, Dziedzic M, et al. Rola metaloproteinaz macierzy zewnątrzkomórkowej w mechanizmach uszkodzeń narządów w przebiegu sepsy. Diagn Lab. 2015; 51: 131-138.

16. Maegdefessel L, Spin JM, Adam M, et al. Micromanaging abdominal aortic aneurysms. Int J Mol Sci. 2013; 14(7): 14374-14394, doi: 10.3390/ijms140714374, indexed in Pubmed: 23852016.

17. Yin $M$, Zhang J, Wang $Y$, et al. Deficient CD4+CD25+ T regulatory cell function in patients with abdominal aortic aneurysms. Arterioscler Thromb Vasc Biol. 2010; 30(9): 1825-1831, doi: 10.1161/ATVBAHA.109.200303, indexed in Pubmed: 20448211

18. Siennicka A, Jastrzębska M. Rola homocysteiny w patogenezie tętniaka aorty brzusznej. Journal of Laboratory Diagnostics. 2012; 48(4): 413-422

19. Wong YYE, Golledge J, Flicker L, et al. Plasma total homocysteine is associated with abdominal aortic aneurysm and aortic diameter in older men. J Vasc Surg. 2013; 58(2): 364-370, doi: 10.1016/j jvs.2013.01.046, indexed in Pubmed: 23643559.

20. Costantino TG, Bruno EC, Handly N, et al. Accuracy of emergency medicine ultrasound in the evaluation of abdominal aortic aneurysm. J Emerg Med. 2005; 29(4): 455-460, doi: 10.1016/j.jemermed.2005.02.016, indexed in Pubmed: 16243207.

21. Xu S, Touyz RM. Reactive oxygen species and vascular remodelling in hypertension: still alive. Can J Cardiol. 2006; 22(11): 947-951, indexed in Pubmed: 16971980.

22. Czyżewska- Bu, Żuk N, Bałasz S, et al. Ocena stężenia osteopontyny i osteoprotegryny u chorych z tętniakiem aorty brzusznej. Przegl Lek. 2013: 70: 102-105

23. Wang SK, Green LA, Gutwein AR, et al. Osteopontin may be a driver of abdominal aortic aneurysm formation. J Vasc Surg. 2018; 68(6S): 22S-29S, doi: 10.1016/j.jvs.2017.10.068, indexed in Pubmed: 29402664.

24. Min H, Morony S, Sarosi I, et al. Osteoprotegerin reverses osteoporosis by inhibiting endosteal osteoclasts and prevents vascular calcification by blocking a process resembling osteoclastogenesis. J Exp Med. 2000; 192(4): 463-474, doi: 10.1084/jem.192.4.463, indexed in Pubmed: 10952716.

25. Moran CS, McCann M, Karan M, et al. Association of osteoprotegerin with human abdominal aortic aneurysm progression. Circu Iation. 2005; 111(23): 3119-3125, doi: 10.1161/CIRCULATIONAHA.104.464727, indexed in Pubmed: 15939823.

26. Golledge J, Muller J, Shephard N, et al. Association between osteopontin and human abdominal aortic aneurysm. Arteriosc-
Ier Thromb Vasc Biol. 2007; 27(3): 655-660, doi: 10.1161/01. ATV.0000255560.49503.4e, indexed in Pubmed: 17170369

27. Norman PE, Davis TME, Le MT, et al. Matrix biology of abdominal aortic aneurysms in diabetes: mechanisms underlying the negative association. Connect Tissue Res. 2007; 48(3): 125-131, doi: 10.1080/03008200701331524, indexed in Pubmed: 17522995.

28. Li T, Jiang Bo, Li X, et al. Serum matrix metalloproteinase- 9 is a valuable biomarker for identification of abdominal and thoracic aortic aneurysm: a case-control study. BMC Cardiovasc Disord. 2018; 18(1): 202, doi: 10.1186/s12872-018-0931-0, indexed in Pubmed: 30373522.

29. Wang Yi, Tang C, Qin Y. Cathepsins: a new culprit behind abdominal aortic aneurysm. Regen Med Res. 2013; 1(1): 5, doi: 10.1186/2050490X-1-5, indexed in Pubmed: 25984324.

30. Shi GP, Dolganov GM. Comprehensive transcriptome of proteases and protease inhibitors in vascular cells. Stroke. 2006; 37(2): 537-541, doi: 10.1161/01.STR.0000198816.62266.e9, indexed in Pubmed: 16373647

31. Klaus V, Schmies F, Reeps C, et al. Cathepsin S is associated with degradation of collagen I in abdominal aortic aneurysm. Vasa. 2018; 47(4): 285-293, doi: 10.1024/0301-1526/a000701, indexed in Pubmed: 29624112.

32. Lu H, Rateri DL, Bruemmer D, et al. Novel mechanisms of abdominal aortic aneurysms. Curr Atheroscler Rep. 2012; 14(5): 402-412, doi: 10.1007/s11883-012-0271-y, indexed in Pubmed: 22833280.

33. Morris DR, Biros E, Cronin O, et al. The association of genetic variants of matrix metalloproteinases with abdominal aortic aneurysm: a systematic review and meta-analysis. Heart. 2014; 100(4): 295-302, doi: 10.1136/heartjnl-2013-304129, indexed in Pubmed: 23813847.

34. Jones GT, Bown MJ, Gretarsdottir S, et al. A sequence variant associated with sortilin-1 (SORT1) on 1p13.3 is independently associated with abdominal aortic aneurysm. Hum Mol Genet. 2013; 22(14): 2941-2947, doi: 10.1093/hmg/ddt141, indexed in Pubmed: 23535823.

35. Biros E, Norman PE, Jones GT, et al. Meta-analysis of the association between single nucleotide polymorphisms in TGF- receptor genes and abdominal aortic aneurysm. Atherosclerosis. 2011; 219(1): 218-223, doi: 10.1016/j.atherosclerosis.2011.07.105, indexed in Pubmed: 21855067

36. Gretarsdottir S, Baas AF, Thorleifsson G, et al. Genome-wide association study identifies a sequence variant within the DAB2IP gene conferring susceptibility to abdominal aortic aneurysm. Nat Genet. 2010; 42(8): 692-697, doi: 10.1038/ng.622, indexed in Pubmed: 20622881.

37. Elmore JR, Obmann MA, Kuivaniemi $\mathrm{H}$, et al. Identification of a genetic variant associated with abdominal aortic aneurysms on chromosome 3p12.3 by genome wide association. J Vasc Surg. 2009; 49(6) : 1525-1531, doi: 10.1016/j.jvs.2009.01.041, indexed in Pubmed: 19497516.

38. Galora S, Saracini C. Pratesi G, et al. Association of rs1466535 LRP1 but not rs3019885 SLC30A8 and rs6674171 TDRD10 gene polymorphisms with abdominal aortic aneurysm in Italian patients. J Vasc Surg. 2015; 61(3): 787-792, doi: 10.1016/j.jvs.2013.10.090, indexed in Pubmed: 24423473

39. Toghill BJ, Saratzis A, Harrison SC, et al. The potential role of DNA methylation in the pathogenesis of abdominal aortic aneurysm. Atherosclerosis. 2015; 241(1): 121-129, doi: 10.1016/j.atherosclerosis.2015.05.001, indexed in Pubmed: 25974102.

40. Gäbel G, Northoff BH, Weinzierl I, et al. Molecular Fingerprint for Terminal Abdominal Aortic Aneurysm Disease. J Am Heart Assoc. 2017; 6(12), doi: 10.1161/JAHA.117.006798, indexed in Pubmed: 29191809. 